\title{
Goods and Services Tax (GST): A Revolutionary Step towards Economic Unification
}

\author{
M. P. Akhil \\ Research Scholar, Department of Commerce, University of Kerala, India \\ E-Mail: akhil.xperia@gmail.com
}

\begin{abstract}
GST is a comprehensive tax system that subsumed all indirect taxes of states and central governments and unified economy into a seamless national market .Under the erstwhile indirect tax regime, there were a number of taxes. Prof. Kelkar Committee has proposed a uniform Goods and Services Tax (GST) to do away with the issues and problems of VAT. Based on Kelkar Committee recommendations, the Govt of India has brought a Bill in 2011 through the Constitution (115th Amendment) (GST) Bill, 2011. However the bill was not passed due to dissolution of 15th Lok Sabha. Again, Constitution (122nd Amendment) (GST) Bill, 2014 was presented in the Lok Sabha and this Bill has been passed in the Lok Sabha as well as Rajyasabha. Goods and service tax is a new story of VAT which gives a widespread setoff for input tax credit and subsuming many indirect taxes from state and national level. The Government's GST regime seeks to replace excise duty, import duties, VAT and service tax regulations, along with other Cess and surcharges, with three separate legislations namely CGST, SGST and IGST. GST would be applicable to all transactions of goods and service, and it to be paid to the accounts of the Centre and the States separately. The biggest advantage of GST is economic unification of India. It has potential to end the longstanding distortions arising out of the differential treatment of the manufacturing and service sectors. It is an issue if people are still unaware or confuse with the tax system of GST and become worst when people ignore and boycott not to pay the tax.
\end{abstract}

Keyword: GST, VAT, Cascading Effect, Economic Unification

\section{INTRODUCTION}

The word tax is derived from the Latin word 'taxore' which means to estimate. Tax is not a voluntary payment or donations as such; it is a compulsory monetary contribution, exacted pursuant to legislative authority and is any contribution imposed by government to meet its expenditure in welfare activities without any corresponding benefit to the taxpayer. Power to levy and collection of taxes emerges from the constitution of India. Article 246 of the constitution of India gives the respective authority to union and state governments for levying taxes. Tax is the major source of revenue for the governments. Tax policies have an important role in the economy. A good tax system shall endeavor to generate tax revenues to support government expenditure incurred on public services and infrastructure developments. Taxes can be broadly divided into two types viz. Direct and Indirect taxes.

Indirect taxes contribute more than $70 \%$ of share, compared to direct tax. Indirect taxes are the taxes which are levied on a product or a service, the incidence of which is borne by the consumers who ultimately consume the product or the service, while the immediate liability to pay the tax may fall upon another person such as manufacturer or seller of goods. Charges levied by the State on consumption, expenditure, privilege, or right, but not on income or property are called Indirect Taxes. Since mid-1980s, the growth in Indian GDP has gone hand in hand with the rise of direct taxes plus a decline in indirect taxes. At a peak of 1988, the government collected nearly a tenth of GDP as indirect taxes.. Equally, the recent fall in economic growth has been accompanied by an increase in indirect taxes and decline in share of direct taxes. There is an inverse link between indirect taxes and economic growth, according to Devendra pant, chief economist, "indirect taxes are like an across-the-board consumption tax, which hits the poor more than the rich. As the poor devote a higher share of their incremental income to consumption, a greater share of their incomes is spent on taxes than the rich whose consumption to income ratio is lower. This lowers the overall demand in the economy and economic growth suffers". So there comes the need to reform tax system,especially indirect tax as it has become a burden for common man.

\section{OBJECTIVES OF THE STUDY}

1. To study the concept of Goods and Services tax (GST) and its role on unification of Indian economy.

2. To know the benefit of goods and service tax to economy.

3. To understand how GST will work in India.

\section{RESEARCH METHODOLOGY}

The studyis is descriptive in nature based on the secondary data sourced from journals articles and media reports. Available secondary data was extensively used for the study.

\section{CONCEPT AND STRUCTURE OF GST}

Goods and Services Tax (GST) is a comprehensive tax levy on manufacture, sale and consumption of goods and service at a national level. Insimpleterms,GST may be defined as a tax on goods and services, which is leviable a teach point of sale or provision of service, in which at the time of sale of goods or providing services the seller or service provider 
may claim the input credit of tax which he has paid while purchasing the goods or procuring the service. It is basically a tax on final consumption.

The present GST comprises:

1. Central GST(CGST) which will be levied by Central Government.

2. State GST(SGST) which will be levied by state government.

3. Integrated GST (IGST) which will be levied by Central Government on inter-State supply of goods and services. This will be CGST plus SGST.

The GST shall subsume all the following indirect taxes, except the Basic Customs Duty ,that will continue to be charged even after the introduction of GST.

TABLE I TAXES SubSUMEDING To GST SySTEM

\begin{tabular}{|l|l|l|}
\hline \multicolumn{1}{|c|}{ Central Levies } & \multicolumn{1}{c|}{ State Levies } & \multicolumn{1}{c|}{ Levies notinpurview of GST } \\
\hline Central Excise duty & VAT,Salestax & $\begin{array}{l}\text { Levies on items containing alcohol } \\
\text { and petroleum products to remain } \\
\text { statusquo. }\end{array}$ \\
\hline Additional Excise duty & Entertainmenttax & $\begin{array}{l}\text { Excise duty by centre on tobacco } \\
\text { products may continue. }\end{array}$ \\
\hline $\begin{array}{l}\text { Excise duty on Medicinal and Toilet } \\
\text { preparations }\end{array}$ & Luxurytax & \\
\hline ServiceTax & $\begin{array}{l}\text { Taxes on lottery, Betting and } \\
\text { gambling }\end{array}$ & \\
\hline Countervailing duty (CVD) & State cessesand surcharges & \\
\hline SpecialAdditionalduty (SAD) & Entrytaxwhichis not lieu of Octroi & \\
\hline Surcharges andcesses & Purchasetax & \\
\hline
\end{tabular}

TABLE II DUAL GST CHART

\begin{tabular}{|l|c|c|l|}
\hline \multicolumn{1}{|c|}{ Transaction } & Old System & New System & \multicolumn{1}{c|}{ Comments } \\
\hline $\begin{array}{l}\text { Sale within the } \\
\text { State }\end{array}$ & $\begin{array}{c}\text { VAT/Excise/ } \\
\text { Sales Tax }\end{array}$ & $\begin{array}{c}\text { SGST and } \\
\text { CGST }\end{array}$ & $\begin{array}{l}\text { Under new system, sales within state will have } \\
\text { two taxes, SGST goes to state and CGST goes to } \\
\text { centre }\end{array}$ \\
\hline $\begin{array}{l}\text { Sale outside the } \\
\text { State }\end{array}$ & CST/ Excise/ Sales Tax & IGST & $\begin{array}{l}\text { Under new system, sales outside state will attract } \\
\text { one tax IGST which goes to centre. }\end{array}$ \\
\hline
\end{tabular}

\section{HISTORICAL BACKGROUND OF GST}

Problems with existing VAT system- to do away with existing various types of indirect taxes specially sales taxes and problems there upon VAT is introduced in India in a fractured manner where some states adopted VAT and some other states have sales taxes. This fractured adoption of VAT system gives rise to number of problems like Differential tax treatment, movementof goods from a VAT state to a non-VAT state, Phasing out of CST completely, Incentive\& Exemption Schemes, No Uniformity in tax rates. In terms of different types of taxes levied by different states economically India is disintegrated. There are greater variationsin prices of goods and services across states in India due to different types of indirect taxation system followed by different states.

To overcome these challenges and problems and to have single integrated indirect taxation system Prof. Kelkar Committee has proposed a uniform Goods and Service Tax (GST). Based on Kelkar Committee recommendations the GOI has brought a Bill in 2011 through the Constitution (115th Amendment) (GST) Bill, 2011. However the bill was not passed due to dissolution of 15th Lok Sabha. Again, Constitution (122nd Amendment) (GST) Bill, 2014 waspresented in the Lok Sabha and this Bill has been passed in the Lok Sabha on May 6, 2015 and referred to a Select Committee of Rajya Sabhafor examination. NDA government is trying to get assent of Rajyasabha in the present session of the parliament.

The issue of cascading taxation was partly addressed through the VAT regime. However, certain problems remained. For example, several central and state taxes were excluded from VAT. Sectors such as real estate, oil and gas production etc. were exempt from VAT. Further, goods and services were taxed differently, thereby making the taxation of products complex. Some of these challenges are sought to be overcome with the introduction of the Goods and Services Tax (GST). The GST is a landmark in the Indian indirect taxation history; this tax regime intends to subsume most indirect taxes under a single taxation regime. GST is a value added tax levied across goods and services. This is expected to help broaden the tax base, increase tax compliance, and reduce economic distortions caused by inter-state variations in taxes.

\section{SALIENT FEATURES OF GST}

The GST Council has decided the final structure of GST as follows:

1. The threshold limit for exemption from levy of GST is 
Rs. 20 lakh for the States except for the Special Category, where it is Rs 10 Lakh.

2. A four slab tax rate structure of 5 percent, 12 percent, 18 percent and 28 percent has been adopted for GST.

3. A cess would be levied on certain goods such as luxury cars, aerated drinks, and pan masala and tobacco products, over and above the GST rate of 28 percent for payment of compensation to the states.

4. The threshold for availing the Composition scheme is Rs. 1.5 and they are required to file quarterly returns only. Certain categories of manufacturers, service providers (except restaurants) are out of the Composition Scheme.

5. GST envisages all transactions and processes to be done only through electronic mode, to achieve nonintrusive administration. This will minimise tax payer's physical interaction with the tax officials.

6. GST provides for the facility of auto-populated monthly returns and annual return.

7. It also facilitates the taxpayers by prescribing grant of refund within 60 days, and provisional release of 90 percent refund to exporters within 7 days. Further facilitation measures include interest payment if refund is not sanctioned in time, and refund to be directly credited to bank accounts.

8. Comprehensive transitional provisions for ensuring smooth transition of existing taxpayers to GST regime, credit for available stocks, etc. •

9. Other provisions include system of GST Compliance Rating, etc.

10. Anti-profiteering provisions for protection of consumer rights.

\section{POSITIVE EFFECTS OF GST}

Implementation of a single National GST will have major beneficial impact on all stake holders. The key highlight of such impact is given below:

\section{A. Eliminates Cascading Effect and Barrier Free Tax Structure}

GST will eliminate cascading [tax on tax/ compounding tax] impact on the production and distribution cost of goods and services. This reduced cost of goods and service leading to accelerated GDP growth. GST without tax barriers will leads to economies of scale in manufacturing industry and reduces the supply chain cost.

\section{B. Expected to Reduce the Production Cost}

GST is expected to reduce the production cost by $15 \%$ to $20 \%$ in many of the products in view of full input tax credit which will have favorable impact on the prices of product.

\section{Expected to Increase the Taxrevenue}

GST will widen the tax base and improve the tax compliance higher tax: GDP ratio. The Tax: GDP ratio is expected to increase by $2 \%$ as per FRBM report. This works out to rupees 70,000 to 80000 crores of additional annual revenue to the central and state governments.

\section{Leads to Sustainable Growth in the Economy}

GST will remove the tax distortions from the economy. This will lead to sustainable higher growth based on competitive strength of the country. Simple tax system will attract more productive investment for growth.

\section{E. Will Lead to Optimization and Comparative Cost Advantage}

GST will eliminate the Inter State tax by which it will leads to optimization of physical facilities to the extent of full capacity. If the manufacturing is done at full capacity industry will be benefited by comparative cost advantage.

\section{F. Increase in the Gdp and Standard of Living}

Since it is expected that with the implementation of GST the price level will reduced in the economy, it will results in increase in the consumption level and growth in GDP of the economy. According to study by NCAER (National Council for Applied Economics and Research) complete implementation of GST could lift GDP growth by $0.9-1.7 \%$.

\section{G. Positive Effects on Export and Bop Level}

In proposed GST the exporter will get the full tax credit, the export units will be able to quote better price for their products and services in comparison with present scenario. Increased export will ultimately have positive effect on the BOP of the country.

\section{H. Will Lead to Reducedchance for Taxevasion}

Since the proposed GST will charges full tax on the each and every transfer, it's difficult for the firms to evade tax from the payment. E.g.: e-commerce firms can't evade tax by operating business from the place where tax rates are comparatively less.

\section{Leads to Centralized Where Housing Formanufacturers}

In the present tax system if the dealer and the ware house are from different states, then the dealer needs to pay a Central Sales Tax of about 2\%.This will increases the price of the commodity. Thus companies use to setup a warehouse in each state. In GST as the CST gets eliminated, the centralized where housing can be availed by the manufacturers.

J. Makes the Tax Structure Simple and Reduces the Compliances

Multiple taxes that currently exist will no longer remain in the picture. This will reduces the compliances to be fulfilled as compared to present situation. 


\section{NEGATIVE EFFECTS OF GST}

The proposed GST may lead to following negative impact on the stake holders.

\section{A. Negatively Affect the Price Level of Essential Goods and Services}

The proposed GST may lead to increase the price of essential products and services which are presently exempted from the taxation.

\section{B. Negative Effect on the Real Estate Industry}

As per the study undertaken by the Curtin University of Technology, Perth in 2000, GST would negatively impact the real estate market as it would add up to $8 \%$ to the cost of new homes and reduce demand by about $12 \%$.

\section{Negative Effect on Working Capital}

As the firms are suppose to make the payment of the tax on every transfer the companies working capital requirement will shoots up by proportional to the purchase of inputs for the value addition.

\section{Emergence of Transfer Pricing Issues}

As the GST considers all the transaction for taxation purpose, this procedure will increases the price of the transfer from one department to another for further process.

\section{GST: 'ONE NATION, ONE TAX'}

Goods and Services Tax (GST) is the biggest tax reform in the country which is happened on 1st july 2017, the Government has brought the entire country under one tax system. India was economically fragmented since past seventy years. There was no economic integration with all the states having their own tax structure and their rules and regulations to impose and collect taxes. Before the onset of the GST, the indirect tax scene in India was fairly chaotic; it was "one nation, many taxes". With GST, the whole country will be bound with 'one tax' implying all the states will have one tax structure. There will be uniformity and india will be "One nation, One tax".

GST promises to subsume India's bottleneck of local and national levies into a single payment, thus unifying the country's 29 states and 1.3 billion people into a common market for the first time. Few countries are worse than India when it comes to paying taxes; the World Bank ranks it 157th out of 189 for simplicity. Both the central government and powerful state legislatures impose an array of charges. Because the rates differ between states, making stuff in one and selling it in another is often harder within India than it is in trade blocs such as NAFTA or the European Union. Queues of lorries idle at India's state boundaries much in the same way they do at international borders. A common and uniform indirect tax code across the country with 37 different tax jurisdictions, 16 different tax levies and 15 kinds of cesses/surcharges under eight different constitutional entries called for a grand unification across legal frameworks, IT systems and tax administration systems.

\section{CONCLUSION}

There are some contentious issues like (a) the treatment of taxes on services with inter-state coverage. With respect to services such as transportation of passengers or goods in railways or telecom, the place of sale and payment and the place of consumption may not coincide and allocation of revenues will have to be negotiated and settled. (b) Setting up of administrative system for GST and working out the transitional arrangements to reduce the compliance cost and to harmonize the administrative processes with uniform systems, forms and procedures.(c) Training up the tax collectors in the administration and enforcement of the GST.In India with robust IT backbone connecting all state governments, trade and industry, banks and other stakeholders on a real-time basis definitely make the GST system a successful one. No doubt the GST by subsuming large number of indirect taxes and having a uniform Indirect tax structure throughout the country will definitely boost up economic unification of India. Again with better conformity and revenue resilience. It will evade the cascading effect in Indirect tax regime. The GST has helped us transition from "one nation, many taxes" to "one nation, one tax". It has been a wonderful lesson in co-operative federalism, one which is in the process of transforming India into a common market by bringing about economic integration in an already integrated polity.

\section{REFERENCES}

[1] Girish Garg. (2014). Basic Concepts and Features of Good and Service Tax In India. International Journal of scientific research and management (IJSRM), 2(2).

[2] Nitin Kumar (2014). Goods and Services Tax in India: A Way Forward. Global Journal of Multidisciplinary Studies, 3(6).

[3] Raghuram, G. \& Deepa, K. S. (2015). Goods and Services Tax: The Introduction Process, Indian Institute of Management, Ahmedabad, India.

[4] An Insight of GST in India. The Institute of Cost Accountants of India (2015). 1.

[5] Kavita Rao, R. and Pinaki Chakraborty. (2013). Revenue Implications of GST and Estimation of Revenue Neutral Rate:A StateWise Analysis, National Institute of Public Finance and Policy, New Delhi.

[6] Retrived from http://www.relakhs.com/gst-goods-services-tax-in ind ia/\#

[7] Retrived from www.cbic.gov.in.

[8] Retrived from http://timesofindia.indiatimes.com/ 